\title{
Multidecadal ocean variability and NW European ice sheet surges during the last deglaciation
}

\section{Paul C. Knutz, Ian R. Hall, and Rainer Zahn}

Department of Earth Sciences, Cardiff University, P.O. Box 914, Cardiff CF10 3YE, UK (knutz@cardiff.ac.uk;

Hall@cardiff.ac.uk; rainer@ocean.cf.ac.uk)

Tine L. Rasmussen

Department of Geology, University of Svalbard, N-9170 Longyearbyen, Norway (tine.rasmussen@unis.no)

\section{Antoon Kuijpers}

Geological Survey of Denmark and Greenland, Øster Voldgade 10, DK-1350, Copenhagen, Denmark (aku@geus.dk)

\section{Matthias Moros}

Baltic Sea Research Institute, Seestrasse 15, 18119 Rostock, Germany (matthias.moros@io-warnemuende.d400.de)

\section{Nicholas J. Shackleton}

Department of Earth Sciences, Godwin Laboratory, Pembroke Street, University of Cambridge, Cambridge CB2 $3 S A$, UK (NJS5@cam.ac.uk)

[1] A multiproxy paleoceanographic record from the Atlantic margin off the British Isles reveals in unprecedented detail discharges of icebergs and meltwater in response to sea surface temperature increases across the last deglaciation. We observe the earliest signal of deglaciation as a moderate elevation of sea surface temperatures that commenced with a weakly developed thermocline and the presence of highly ventilated intermediate waters in the Rockall Trough. This warming pulse triggered a series of multidecadal ice-rafted debris peaks that culminated with a major meltwater discharge at 17,500 years before present related to ice sheet disintegration across the NW European region. The impact of meltwater caused a progressive reduction in deep water ventilation and a sea surface cooling phase that preceded the collapse of the Laurentide Ice Sheet during Heinrich event 1 by 500-1000 years. A similar sequence of rapid ocean-ice sheet interaction across the European continental margin is identified during the BøllingAllerød to Younger Dryas transition. The strategic location of our sediment core suggests a sensitive and rapid response of ice sheets in NW Europe to transient increases in thermohaline heat transport.

Components: 5319 words, 2 figures, 1 table.

Keywords: Last deglaciation; ice rafted debris; stable isotopes; meltwater; north east Atlantic; thermohaline circulation.

Index Terms: 3022 Marine Geology and Geophysics: Marine sediments-processes and transport; 4267 Oceanography: General: Paleoceanography; 4870 Oceanography: Biological and Chemical: Stable isotopes.

Received 25 March 2002; Revised 28 June 2002; Accepted 15 July 2002; Published 17 December 2002.

Knutz, P. C., I. R. Hall, R. Zahn, T. L. Rasmussen, A. Kuijpers, M. Moros, and N. J. Shackleton, Multidecadal ocean variability and NW European ice sheet surges during the last deglaciation, Geochem. Geophys. Geosyst., 3(12), 1077, doi:10.1029/2002GC000351, 2002. 


\section{Introduction}

[2] Abrupt shifts in North Atlantic climate records indicate a strong link between the meridional heat flux driven by thermohaline convection and glacimarine discharges from the Late Pleistocene ice sheets [Ruddiman and McIntyre, 1981; Lehman and Keigwin, 1992; Bond et al., 1993]. The impact of meltwater on thermohaline circulation is often invoked as a forcing factor for rapid climate change [Ganopolski and Rahmstorf, 2001], although the mechanism for promoting submillennial scale instability of marine ice margins remains unclear [Bond and Lotti, 1995; van Kreveld et al., 2000]. The massive discharges of icebergs during Heinrich events have been related to periodic collapses of the Laurentide Ice Sheet (LIS) [MacAyeal, 1993], but internal ice sheet dynamics cannot explain the 1-2 ka cycle of glacial fluctuations that is related to the stadial events of the Greenland summit climate record [Bond and Lotti, 1995]. There is increasing evidence that this millennialscale ice-rafted debris (IRD) signal was produced by ice sheets that were much smaller than the LIS and directly influenced by ocean climate [Fronval et al., 1995; Elliot et al., 1998; Knutz et al., 2001]. The position of the Icelandic, Fennoscandian, and British ice sheets in vicinity of the main path of the North Atlantic Drift which presently feeds the thermohaline overturn cell in the Nordic Seas [McCartney and Talley, 1984], provides the potential for a close coupling between oceanic heat transport and glacial mass balances. A differential response between circum-North Atlantic ice sheets, possibly linked to changes in the thermohaline circulation, has been suggested from IRD provenance studies across Heinrich events 1 and 2 [Grousset et al., 2000; Scourse et al., 2000]. Here we present a paleoclimatic record of the last deglaciation from the NE Atlantic margin, which provides new evidence of multidecadal scale interaction between ocean circulation and sensitive ice sheets in NW Europe.

\section{Material and Methods}

[3] Core DAPC2 was retrieved from a contourite drift deposit located SE of Rosemary Bank, north- ern Rockall Trough $\left(58^{\circ} 58.10^{\prime} \mathrm{N}, 09^{\circ} 36.75^{\prime} \mathrm{W}\right)$ at a water depth of $1709 \mathrm{~m}$ (Figure 1). The site is at present influenced by Norwegian Sea Overflow Water (NSOW; a precursor water mass of North Atlantic Deep Water, NADW) crossing the Wyville-Thomson Ridge [Ellett and Roberts, 1973; New and Smythe-Wright, 2001] and recirculated NADW [McCartney, 1992]. The chronology of DAPC2 is constrained by seven ${ }^{14} \mathrm{C}$-AMS datings (Table 1) and a stratigraphic control point, which relates a sharp increase in foraminiferal abundances to the YD-Holocene transition of the GRIP $\delta^{18} \mathrm{O}$ profile (Supplementary Information, available at http://www.g-cubed.org). A calendar year timescale was derived from the linear extrapolation between age control points using CALIB 4.1 [Stuiver et al., 1998], which included a marine reservoir correction of 400 years. The marine ${ }^{14} \mathrm{C}$ reservoir age is known to have varied across the last deglaciation in response to ocean circulation changes and atmospheric ${ }^{14} \mathrm{C}$ production rates [Voelker et al., 1998] so the timescale represents a first order approximation. Sedimentation rates average $23 \mathrm{~cm} \mathrm{ka}^{-1}$ across the last deglaciation, encompassing the Younger Dryas (YD), BøllingAllerød (B-A) and Heinrich event 1 (H-1), increasing to $>70 \mathrm{~cm} \mathrm{ka}^{-1}$ across the interval associated with the late glacial-early deglaciation. Similarly high sedimentation rates have previously been observed in glacial sections of contourite deposits from the Rockall Trough and are probably related to deposition from meltwater plumes emanating from the western European shelf margins [Knutz et al., 2001; Lassen et al., 2002]. Samples were obtained at $2 \mathrm{~cm}$ intervals, enabling us to recognize paleoceanographic shifts at a multidecadal temporal resolution. The high sedimentation rates and the sharpness of the proxy signals observed in DAPC2 suggest that the influence of bioturbation is negligible [Anderson, 2001]. Nevertheless, should a small amount of bioturbational blurring of the paleoclimatic signals have occurred, then the speed of the events recorded in DAPC2 is likely to be faster than we claim here.

[4] The relative abundance of the polar foraminifera Neogloboquadrina pachyderma sinistral (Nps) in the $>125 \mu \mathrm{m}$ fraction was counted in 


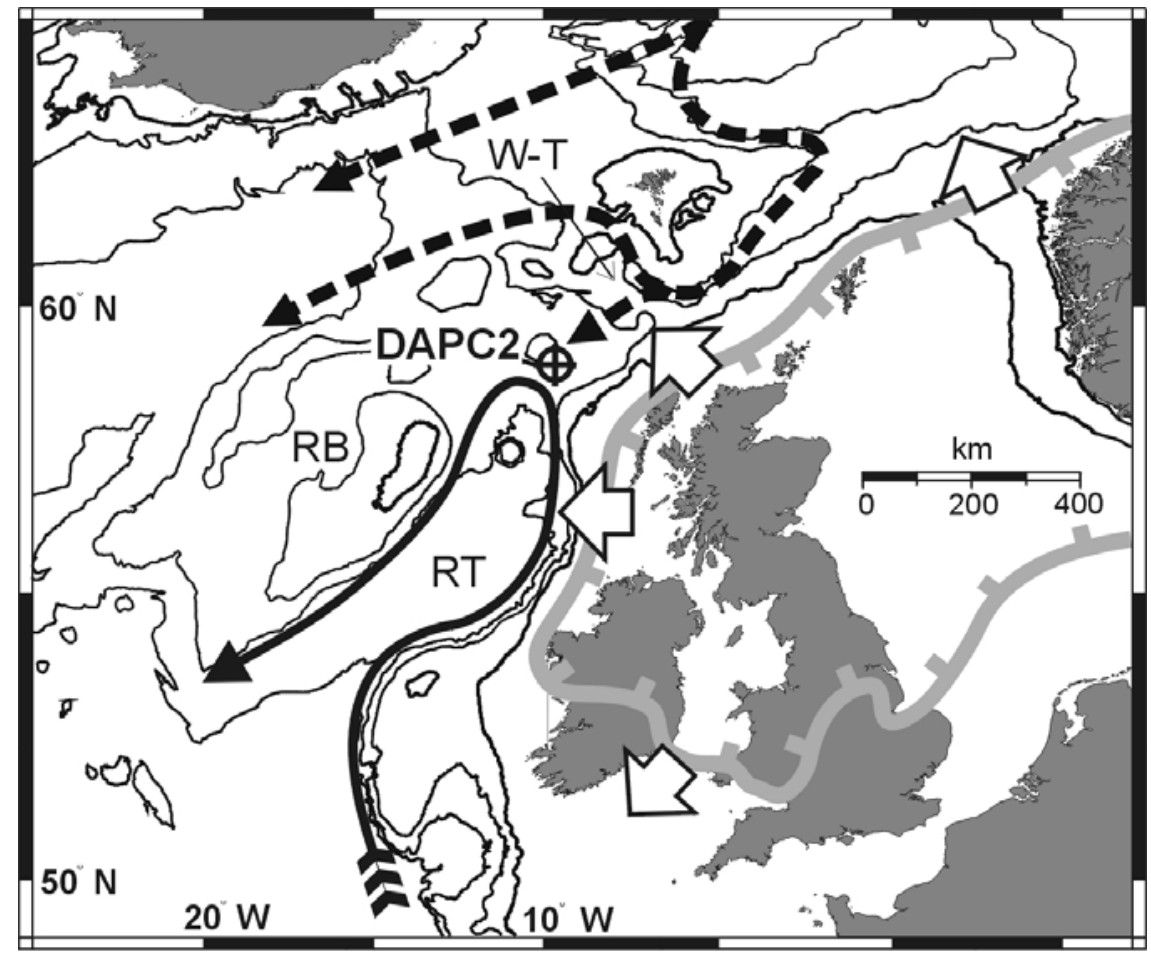

Figure 1. Location of core DAPC2, modern deep ocean circulation and the extend of the LGM ice sheet in NW Europe. Broad arrows indicate the main glacimarine outlets [McCabe and Clark, 1998; Knutz et al., 2001]. The thin, black arrow illustrates a northerly boundary current driven by recirculated North Atlantic Deep Water, which flows along the European continental slope at depths of 2-3 km [McCartney, 1992]. The broken arrow represents Norwegian Sea Overflow Water, which enters the northeast Atlantic across the shallow sills between Iceland and Scotland [Ellett and Roberts, 1973; New and Smythe-Wright, 2001]. RB: Rockall Bank, RT: Rockall Trough, W-T: Wywille-Thomson Ridge. Contours represent $200 \mathrm{~m}$ (thick line), 1000, 2000 and $3000 \mathrm{~m}$ (thin lines) water depth.

sample splits containing $>300$ specimens, as a relative indicator of sea surface temperature (SST) changes. In the North Atlantic this species makes up more than $95 \%$ of the planktic faunal assemblage at summer SSTs below $5^{\circ} \mathrm{C}$ [Johannessen et al., 1994]. The abundance of detrital components (grains per gram dry bulk sediment) was analyzed in the $>250 \mu \mathrm{m}$ fraction. The fractured quartz (FQ) component provides a positive indicator of iceberg-transported debris [Knutz et al., 2001], while the content of detrital carbonate (DC) is related to deposition from distal icebergs derived from the LIS [Andrews and Tedesco, 1992]. The FQ flux was calculated from the FQ abundance and bulk mass accumulation rates (Supplementary Information, available at http://www. g-cubed.org). The stable isotope composition of planktonic foraminifera species Nps and Globigerina bulloides $(G b)$, and the epibenthic species Cibicidoides wuellerstorfi $(\mathrm{Cw})$ was determined using a Micromass Multiprep system attached to a VG PRISM mass spectrometer. $\delta^{18} \mathrm{O}$ and $\delta^{13} \mathrm{C}$ values are reported relative to the Vienna Peedee belemnite (VPDB) international standard with analytical precision better than $\pm 0.06 \%$. The content of sortable silt $(10-63 \mu \mathrm{m})$ was measured on a Sedigraph grain size analyzer subsequent to removal of calcium carbonate using $2 \mathrm{M}$ acetic acid. In contourite drift sediments, this parameter is primarily related to relative changes in flow speed of nearbottom currents [McCave et al., 1995b].

\section{Rapid Ocean-Ice Sheet Responses}

[5] Major events of increased supply in ice-rafted debris during the Younger Dryas and the early deglaciation are clearly recognized by the flux of FQ (Figure 2b). The ratio between DC and FQ grains provides a signal of icebergs discharged from the Hudson Bay region of the LIS and pinpoints the 


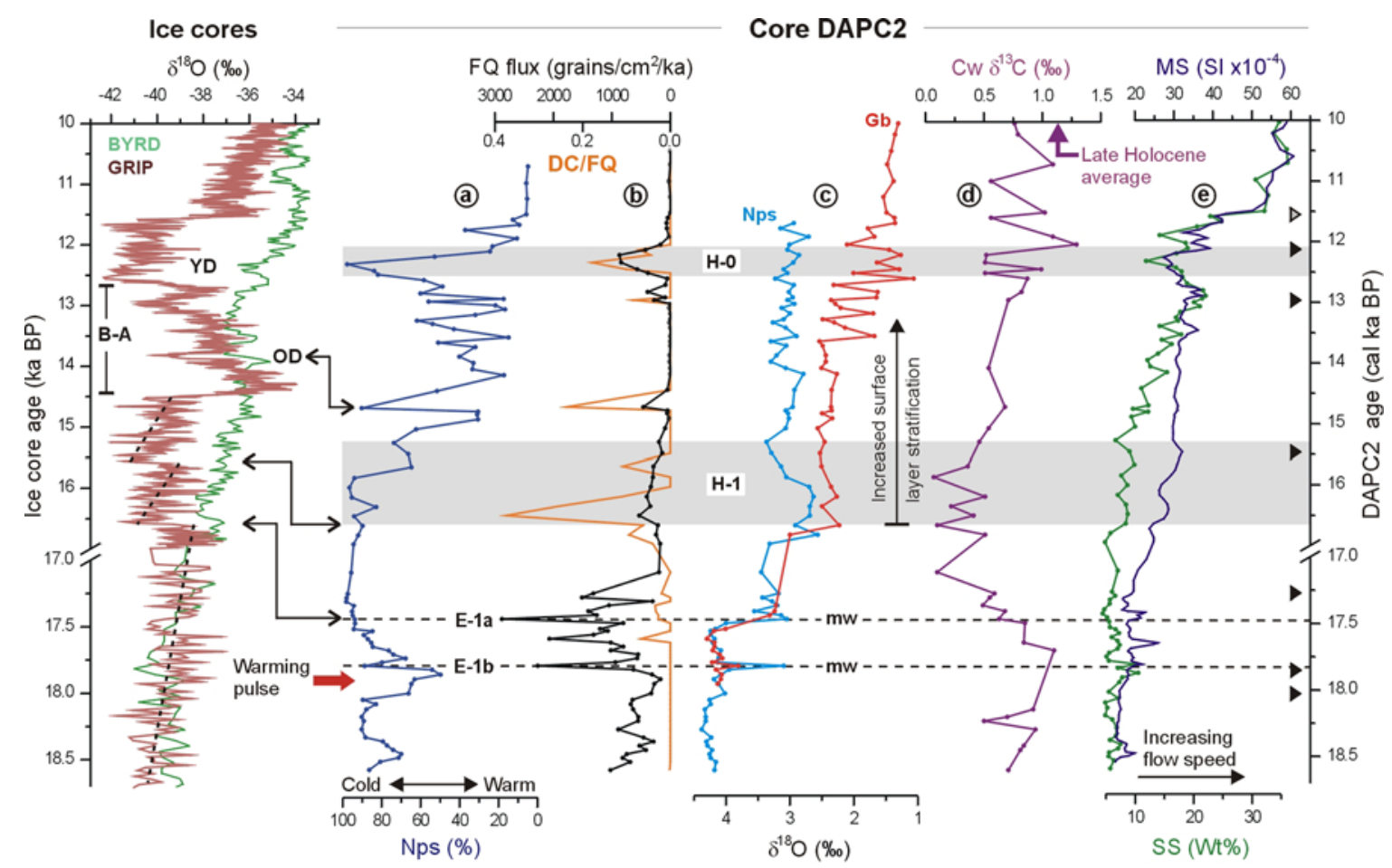

Figure 2. Paleoceanographic time series from core DAPC2. (a) Relative abundance of the polar foraminifera Neogloboquadrina pachyderma sinistral (Nps) in the $>125 \mu \mathrm{m}$ fraction. (b) Flux of ice-rafted, fractured quartz (FQ) (number of grains $\mathrm{cm}^{-2} \mathrm{ka}^{-1}$ ) and the ratio of pale-yellowish detrital carbonate (DC) to FQ. (c) Oxygen isotope records $\left(\delta^{18} \mathrm{O}\right)$ of planktonic foraminifera Nps and Globigerina bulloides $(\mathrm{Gb})$. (d) Carbon isotope record $\left(\delta^{13} \mathrm{C}\right)$ of epibenthic foraminifera Cibicidoides wuellerstorf $i(C w)$. The arrow on the scale bar represents an average of late Holocene $C w \delta^{13} \mathrm{C}$ values measured in DAPC2. (e) Records of magnetic susceptibility (MS) and weight percentage of sortable silt (SS\%, 10-63 $\mu \mathrm{m}$ terrigenous fraction). Heinrich events (H-1, H-0), European glacimarine events (E-1 $1_{\mathrm{a}-\mathrm{b}}$ ), Bølling-Allerød (B-A), Older Dryas (OD), and Younger Dryas (YD) are indicated. The FQ flux was calculated from the grain abundance and bulk mass accumulation rates (Supplementary Information, available at http://www.gcubed.org). The timescale is based on linear interpolation of 7 AMS ${ }^{14} \mathrm{C}$ dates (black triangles) performed on singlespecies foraminifera (Table 1), and a stratigraphic control point (gray triangle), which relates a sharp increase in foraminiferal abundances to the YD-Holocene transition in the Greenland summit GRIP $\delta^{18} \mathrm{O}$ record. Left-hand panel shows $\delta^{18}$ O records from GRIP [Dansgaard et al., 1993] and west Antarctic Byrd [Johnsen et al., 1972] ice cores on a common age scale [Blunier and Brook, 2001] allowing comparison with the atmospheric temperature changes in the northern and southern hemisphere. The late glacial warming trends in the GRIP $\delta^{18} \mathrm{O}$ record are depicted by the hatched line. Note the change in timescale at $17 \mathrm{ka}$ BP.

glacial collapse associated with $\mathrm{H}-1$, which in the central North Atlantic IRD belt is dated between 16 and $17 \mathrm{ka}$ before present (BP) [Andrews, 1998]. We also observe a DC peak within the B-A interval, which likely corresponds to the Older Dryas cooling. The sharp centennial-scale IRD peaks observed during the earliest deglaciation between 18 and 17 ka BP (Figure 2b) are outstanding as these occur more than 1500 years prior to the peak of the $\mathrm{H}-1$ event. The two most prominent IRD peaks within the broad IRD increase correlate with sharp $\delta^{18} \mathrm{O}$ depletions suggesting that these are related to regional glacimarine discharges and not just local anomalies
(Figures $2 \mathrm{~b}$ and $2 \mathrm{c}$ ). The relative magnitude of the IRD flux between 18 and $17 \mathrm{ka}$, on average more than three times greater than during $\mathrm{H}-1$, and the sharp meltwater pulses points to a nearby source on the NE Atlantic margin for these events.

[6] The most proximal source for iceberg discharges at this location was the NW sector of the British Ice Sheet, which during the early deglaciation advanced onto the shelf margin west of Scotland [McCabe and Clark, 1998; Knutz et al., 2001] ( $200 \mathrm{~km}$ from the DAPC2 core site). We cannot rule out that other ice sheets along the NE 
Atlantic margins contributed to the earliest deglacial IRD events, in particularly the Fennoscandian Ice Sheet, which drained into the Norwegian Channel to the NE of the British Isles [Sejrup et al., 1994]. However, the low abundance of DC precludes the Hudson Bay region of the LIS as the main source of icebergs. Low DC layers observed between $\mathrm{H}-1$ and $\mathrm{H}-2$ in the Labrador Sea region may reflect a more frequent response from parts of the LIS other than the Hudson Bay ice stream [Stoner et al., 1996], but it is difficult to associate these horizons, apparently of mixed downslope and hemipelagic origin, with the large IRD fluxes of the DAPC2 core between 18 and $17 \mathrm{ka}$ BP. This conclusion leads us to term the glacimarine discharges observed during the earliest deglaciation as European events, E- $1_{\mathrm{a}-\mathrm{b}}$ (Figure 2). We suggest that the E-1 events in DAPC2 are analogues to the European 'precursors' of Heinrich events recently demonstrated on the NE Atlantic margin [Grousset et al., 2000; Scourse et al., 2000].

[7] The E- $1_{a-b}$ events are immediately preceded by a rapid warming pulse in SST, indicated by a sharp reduction in the abundance of Nps (Figure 2a). This warming signal starts abruptly at $\sim 18 \mathrm{ka}$ with an initial change lasting some 50 years. The warming is terminated at $\sim 17.8 \mathrm{ka}$, and SST rapidly cools and returns to its initial late glacial level within several decades. The cooling is coincident with the first glacimarine $\mathrm{E}-1_{\mathrm{b}}$ event, marked by an abrupt negative $N p s \delta^{18} \mathrm{O}$ excursion of $\sim 1 \%$ (Figures $2 \mathrm{a}-2 \mathrm{c}$ ). The $\mathrm{E}-1_{\mathrm{b}}$ peak suggests a rapid glacial response to sea surface warming, possibly related to onset of a fast-flow regime of the British Ice Sheet, driven by high meltwater production along its western margins [McCabe and Clark, 1998]. The E- $1_{\mathrm{a}}$ event at $\sim 17.5 \mathrm{ka}$ BP is characterized by an abrupt $\sim 1 \%$ decrease in planktonic (Nps and $G b) \delta^{18} \mathrm{O}$ occurring over a period of several decades. The negative step change in $\delta^{18} \mathrm{O}$ associated with the E- $1_{\mathrm{a}}$ meltwater pulse suggests a more widespread deglaciation in the NE Atlantic sector, possibly involving the collapse of the Barents Sea ice shelf, which has previously been estimated at $\sim 17 \mathrm{ka}$ [Bischof, 1994; Hebbeln et al., 1994]. The multidecadal resolution expressed by the DAPC2 record allows the E-1 glacimarine events to be clearly discerned from the $\mathrm{H}-1$ event, which is evident as a prolonged negative $N p s \delta^{18} \mathrm{O}$ anomaly between 17 and $16 \mathrm{ka} \mathrm{BP}$ (Figure 2c).

[8] At the end of the B-A warm interval a small increase in IRD at $13 \mathrm{ka} \mathrm{BP}$ is followed by a strong IRD peak between 12.5 and $12.0 \mathrm{ka} \mathrm{BP}$ associated with the $\mathrm{H}-0$ event. The $\mathrm{H}-0$ and the precursor event coincide with a series of negative $G b \delta^{18} \mathrm{O}$ anomalies observed across the B-A to YD transition. However, the first two of the $\delta^{18} \mathrm{O}$ anomalies, between 13.5 and $13.0 \mathrm{ka} \mathrm{BP}$, clearly precede the IRD peaks (Figure $2 \mathrm{c}$ ) and are therefore unlikely to represent a glacimarine meltwater signal. From the proximity of the DAPC2 core to the European continental margin the negative $\delta^{18} \mathrm{O}$ anomalies are more likely to represent glacifluvial discharges produced from terrestrial ice-margins. The paleoclimatic sequence across the Allerød-YD transition supports the rapid response of NW European ice sheets to SST warming similar to that of the earliest deglaciation (Figures 2a and 2b).

\section{Ocean Circulation Changes}

[9] We use information derived from the stable isotope composition of planktonic and benthic foraminifera species to infer changes in North Atlantic circulation and the impact of European meltwater pulses on thermohaline circulation across the last deglaciation (Figures $2 \mathrm{c}$ and $2 \mathrm{~d}$ ). The offset in $\delta^{18} \mathrm{O}$ of foraminiferal species representing surface water $(G b)$ and thermocline water (Nps) provides an indication of the vertical hydrographic structure (temperature, salinity) of the surface ocean layer and its potential for convection [Hillaire-Marcel and Bilodeau, 2000]. Benthic $\delta^{13} \mathrm{C}$, in turn, serves as a paleoceanographic indicator for the relative contributions of nutrientdepleted NADW (high $\delta^{13} \mathrm{C}$ ) and nutrient-enriched water originating from the southern hemisphere (low $\delta^{13} \mathrm{C}$ ) [Kroopnick, 1985]. Prior to the E- $1_{\mathrm{a}}$ meltwater peak at $17.5 \mathrm{ka} \mathrm{BP} N p s$ and $G b \delta^{18} \mathrm{O}$ signals are virtually identical, which suggests that the initial warming pulse at $\sim 18$ ka BP was associated with a well-mixed surface-subsurface layer that is indicative of a weakly developed thermocline and decreased vertical stability of the 
upper water column (Figure 2c). This interpretation is supported by the high benthic $\delta^{13} \mathrm{C}$ values $(>0.8 \%)$ prior to $17.5 \mathrm{ka}$ BP (Figure $2 \mathrm{~d}$ ), which imply the presence of a nutrient-deficient and highly ventilated water mass, presumably Glacial North Atlantic Intermediate Water (GNAIW) that is known to have extended to depths of $\sim 2000 \mathrm{~m}$ [Duplessy et al., 1988; Oppo and Lehman, 1993; Sarnthein et al., 1994]. The decrease in benthic $\delta^{13} \mathrm{C}$ directly following the $\mathrm{E}-1_{\mathrm{b}}$ event suggests that high meltwater fluxes from western Europe caused a progressive reduction in deep water ventilation. This reflects a slow-down in the formation of nutrient-depleted GNAIW, which in the deepest parts of the Rockall Trough became replaced by nutrient-enriched southern source water [Oppo and Lehman, 1993; McCave et al., 1995a]. The general increase in $G b-N p s \delta^{18} \mathrm{O}$ gradients after $\sim 16 \mathrm{ka} \mathrm{BP}$ points to increased stratification and the shoaling of the thermocline during the B-A.

[10] To constrain our palaeoceanograhic interpretation, we have extracted sedimentological properties from DAPC2 that provide a physical indication of changes in thermohaline circulation (Figure 2e). The sortable silt percentage ( $\mathrm{SS} \%$ ) is used as a proxy of near-bottom flow, for which greater abundance suggests faster relative flow speeds [McCave et al., 1995b]. The strong influence of bottom current sediment sorting in core DAPC2 is supported by the positive correlation between $\mathrm{SS} \%$ and magnetic susceptibility, which in other records from the NE Atlantic margin has been linked to the intensity of NSOW [Rasmussen et al., 1996]. The low SS\% values prior to $\sim 17 \mathrm{ka}$ suggest that bottom currents were too weak to produce a measurable sorting effect on the 10-63 $\mu \mathrm{m}$ silt concentrations (Figure 2e). The gradual increase in $\mathrm{SS} \%$ from $\sim 17 \mathrm{ka}$ indicates a progressive strengthening of flow speeds up to a local maximum during the late Allerød warming. Combined with an increase in benthic $\delta^{13} \mathrm{C}$, this points to an increased vigor of deep water recirculation with a gradually increasing contribution from a northern deep water source, and a corresponding weakening of the southern hemisphere water contribution (Figure $2 \mathrm{~d}$ ). We note that the benthic $\delta^{13} \mathrm{C}$ levels during the B-A interval represent a mixed water mass rather than a pure northern source end-member (Holocene $\delta^{13} \mathrm{C}$ values average $1.14 \%$ compared with an average of $0.57 \%$ during the B-A interval). A marked reduction in $\mathrm{SS} \%$ across the YD cooling and an abrupt decrease in $\delta^{13} \mathrm{C}$ at $12.5 \mathrm{ka} \mathrm{BP}$ indicate a transient decrease in deep ventilation suggestive of a close linkage between meltwater injection and convective slow-down in the North Atlantic (Figures $2 \mathrm{~d}$ and $2 \mathrm{e}$ ). Flow speed then increased rapidly in two discrete steps. The first increase occurred immediately after the YD meltwater peak around $12.2 \mathrm{ka}$ (Figure 2c), while the second marks the YDHolocene transition placed at $11.5 \mathrm{ka}$ according to the GRIP $\delta^{18} \mathrm{O}$ record. By analogy with the sharpness of the YD termination in the GRIP ice core (Figure 2) we infer that the transition from the convective slow-down during the YD to a modern circulation regime with full-scale NSOW influence occurred in as little as 60 years.

\section{Discussion and Conclusions}

[11] Comparison of our records with the $\delta^{18} \mathrm{O}$ signal from the GRIP ice core [Dansgaard et al., 1993] reveals a broad correlation between transient shifts in NE Atlantic ocean circulation and the evolution of regional climate during the last deglaciation (Figure 2). The warming pulse observed prior to the E-1 events in DAPC2 is not explicitly revealed in the GRIP ice core but appears to be embedded into the broad temperature increase observed between 18.5 and $16.5 \mathrm{ka}$. According to our correlation the early deglacial warming trend in the GRIP $\delta^{18} \mathrm{O}$ record was aborted by the $\mathrm{E}-\mathrm{1}_{\mathrm{a}}$ meltwater peak. Renewed increase in Greenland air temperatures occurred subsequent to the $\mathrm{E}-\mathrm{1}_{\mathrm{a}}$ event, but again climatic amelioration was disrupted, this time by the H-1 meltwater pulse. The age discrepancies of $1.3-$ $1.6 \mathrm{ka}$ (including the 400 year correction used in the ${ }^{14} \mathrm{C}$ age calibration) that arise from the correlation between the late glacial $\delta^{18} \mathrm{O}$ transitions in the GRIP record and the E-1 and $\mathrm{H}-1$ meltwater pulses in DAPC2 are likely to represent the effects of increased marine ${ }^{14} \mathrm{C}$ reservoir ages [Voelker et al., 1998; Waelbroeck et al., 2001] on our converted, calendar-year timescale. Comparison with the Byrd ice core [Johnsen et al., 1972; Blunier and Brook, 2001] (Figure 2) shows that atmospheric temper- 
Table 1. Radiocarbon Dating Results From Core DAPC2

\begin{tabular}{clcccc}
\hline Laboratory Number & \multicolumn{1}{c}{ Material } & $\begin{array}{c}\text { Depth, } \\
\mathrm{cm}\end{array}$ & $\begin{array}{c}{ }^{14} \mathrm{C} \mathrm{Age,} \\
\text { yr BP }\end{array}$ & $\begin{array}{c}\text { Error Age, } \\
\pm 1 \sigma \text { yr BP }\end{array}$ & $\begin{array}{c}\text { Calendar } \\
\text { Age }\end{array}$ \\
\hline AAR-5209 & G. bulloides & 42 & 8,190 & \pm 90 & 9.067 \\
AAR-5210 & N. pachyderma $(s)$ & 78 & 10,430 & \pm 90 & 12.193 \\
AAR-6304 & N. pachyderma $(s)$ & 96 & 10,980 & \pm 110 & 12.938 \\
AAR-6305 & N. pachyderma $(s)$ & 138 & 13,010 & \pm 130 & 15.458 \\
AAR-5211 & N. pachyderma $(s)$ & 160 & 14,500 & \pm 110 & 17.262 \\
AAR-6306 & N. pachyderma $(s)$ & 199 & 15,000 & \pm 170 & 17.835 \\
AAR-5212 & N. pachyderma $(s)$ & 209 & 15,160 & \pm 140 & 18.014 \\
\hline
\end{tabular}

${ }^{\mathrm{a}}$ Including marine reservoir correction of 400 years.

${ }^{\mathrm{b}}$ Obtained from CALIB 4.1 [Stuiver et al., 1998].

atures over Antarctica continued to increase over this early deglacial period. We surmise that the Byrd temperature record, from its isolated location in Antarctica, is more representative of the mean global evolution of atmospheric temperature. Deviations from this trend, as seen in the GRIP ice core record, are likely a response to the forcing that ocean-ice sheet interaction, notably thermohaline heat transport and meltwater production exerted on North Atlantic climates [Grootes et al., 2001].

[12] Our findings suggest that the initial cooling observed prior to $\mathrm{H}-1$ in many North Atlantic records [Bond et al., 1993; Labeyrie et al., 1999; Bard et al., 2000] is likely to be the effect of meltwater discharge from European ice sheets. However, the mechanism that links the E-1 and $\mathrm{H}-1$ event remains enigmatic. One possibility is that surging of ice sheets in NW Europe acted as a trigger mechanism for $\mathrm{H}-1$ through a sea level rise that over a period of centuries destabilized the marine-based margins of the LIS [Andrews, 1998; Grousset et al., 2000]. This hypothesis is supported by the step-like decrease in $\delta^{18} \mathrm{O}$ at $17.3 \mathrm{ka} \mathrm{BP}$ which marks a major deglaciation of the entire European and Arctic region [Jones and Keigwin, 1988; Hebbeln et al., 1994; Sarnthein et al., 1995]. Alternatively, the time lag between E-1 and H-1 may reflect a slower response of the LIS to a common climatic forcing manifest by the late glacial warming pulse [Scourse et al., 2000]. A phase of climatic amelioration with a maximum around $18-17 \mathrm{ka} \mathrm{BP}$ has previously been documented in the NE Atlantic [Lagerklint and Wright, 1999; Zaragosi et al., 2001] and Scandinavia [Vorren et al., 1988] which points to a regional incursion of temperate water masses along the Euro- pean continental margin. The corollary is that the warming might represent the initial developing stage of a Dansgaard-Oeschger event that was disrupted by glacimarine discharges before it could trigger full-scale thermohaline convection in the Nordic Seas, and consequently produce a sharp temperature increase in the Greenland climate record.

[13] In summary, the records from DAPC2 suggest that a major ice sheet collapse in NW Europe was triggered by a brief warming pulse that punctuated the late glacial-early deglacial interval. The ensuing sequence of ocean-ice sheet interaction in the NE Atlantic appears to have been critical for the glacimarine discharges that subsequently emerged from the Hudson Bay region during H-1. Our results confirm the high sensitivity of the glacial North Atlantic to even minor changes in freshwater fluxes that are demonstrated in ocean-climate models [Ganopolski and Rahmstorf, 2001].

\section{Acknowledgments}

[14] We are grateful to Mike Hall at Godwin Lab, Cambridge University, for technical assistance with the stable isotope analyses. We thank Jan Heinemeier who carried out at the AMS 14C dating at the Radiocarbon Dating Laboratory of Aarhus University. This work was supported by the Natural Environment Research Council.

\section{References}

Anderson, D. M., Attenuation of millennial-scale events by bioturbation in marine sediments, Paleoceanography, 16, 352-357, 2001.

Andrews, J. T., Abrupt changes (Heinrich events) in late Quaternary North Atlantic marine environments: A history and review of data and concepts, J. Quat. Sci., 13, 3-16, 1998. 
Andrews, J. T., and K. Tedesco, Detrital carbonate-rich sediments, northwestern Labrador Sea: Implications for ice-sheet dynamics and iceberg rafting (Heinrich) events in the North Atlantic, Geology, 20, 1087-1090, 1992.

Bard, E., F. Rostek, J. L. Turon, and S. Gendreau, Hydrological impact of Heinrich events in the subtropical Northeast Atlantic, Science, 289, 1321-1323, 2000.

Bischof, J. F., The decay of the Barents ice sheet as documented in nordic seas ice-rafted debris, Mar. Geol., 117, 35-55, 1994.

Blunier, T., and E. J. Brook, Timing of millennial-scale climate change in Antarctica and Greenland during the last glacial period, Science, 291, 109-111, 2001.

Bond, G. C., and R. Lotti, Iceberg discharges into the North Atlantic on millennial time scales during the Last Glaciation, Science, 267, 1005-1010, 1995.

Bond, G., W. Broecker, S. Johnsen, J. Macmanus, L. Labeyrie, J. Jouzel, and G. Bonani, Correlations between climate records from North Atlantic sediments and Greenland ice, Nature, 365, 143-147, 1993.

Dansgaard, W., S. J. Johnsen, H. B. Clausen, D. Dahl-Jensen, N. S. Gundestrup, C. U. Hammer, C. S. Hvidberg, J. P. Steffensen, A. E. Sveinbjörnsdottir, J. Jouzel, and G. Bond, Evidence for instability of past climate from a 250-kyr ice core, Nature, 364, 218-220, 1993.

Duplessy, J.-C., N. J. Shackleton, R. G. Fairbanks, L. Labeyrie, D. Oppo, and N. Kallel, Deep water source variations during the last climatic cycle and their impact on the global deep water circulation, Paleoceanography, 3, 343-360, 1988.

Ellett, D. J., and D. G. Roberts, The overflow of Norwegian Sea Deep Water across the Wyville-Thomson Ridge, Deep Sea Res. Oceanogr. Abstr., 20, 819-835, 1973.

Elliot, M., L. Labeyrie, G. Bond, E. Cortijo, J. L. Turon, N. Tisnerat, and J. C. Duplessy, Millennial-scale iceberg discharges in the Irminger Basin during the last glacial period: Relationship with the Heinrich events and environmental settings, Paleoceanography, 13, 433-446, 1998.

Fronval, T., E. Jansen, J. Bloemendal, and S. Johnsen, Oceanic evidence for coherent fluctuations in Fennoscandian and Laurentide ice sheets on millennium timescales, Nature, 374, 443-446, 1995.

Ganopolski, A., and S. Rahmstorf, Rapid changes of glacial climate simulated in a coupled climate model, Nature, 409, 153-158, 2001.

Grootes, P. M., E. J. Steig, M. Stuiver, E. D. Waddington, D. L. Morse, and M. J. Nadeau, The Taylor Dome Antarctic delta O-18 record and globally synchronous changes in climate, Quat. Res., 56, 289-298, 2001.

Grousset, F. E., C. Pujol, L. Labeyrie, G. Auffret, and A. Boelaert, Were the North Atlantic Heinrich events triggered by the behavior of the European ice sheets?, Geology, 28, $123-126,2000$.

Hebbeln, D., T. Dokken, E. S. Andersen, M. Hald, and A. Elverhoi, Moisture supply for northern ice-sheet growth during the Last Glacial Maximum, Nature, 370, 357-360, 1994.

Hillaire-Marcel, C., and G. Bilodeau, Instabilities in the Labrador Sea water mass structure during the last climatic cycle, Can. J. Earth Sci., 37, 795-809, 2000.
Johannessen, T., E. Jansen, A. Flatøy, and A. C. Ravelo, The relationship between surface water masses, oceanographic fronts and paleoclimatic proxies in surface sediments of Greenland, Iceland, Norwegian Seas, NATO ASI Ser. 1, 17, $61-85,1994$.

Johnsen, S. J., W. Dansgaard, H. B. Clausen, and C. C. Langway Jr., Oxygen isotope profiles through the Antarctic and Greenland ice sheets, Nature, 235, 429-434, 1972.

Jones, G. A., and L. D. Keigwin, Evidence from Fram Strait $\left(78^{\circ} \mathrm{N}\right)$ for early deglaciation, Nature, 336, 56-59, 1988.

Knutz, P. C., W. E. N. Austin, and E. J. W. Jones, Millennialscale depositional cycles related to British Ice Sheet variability and North Atlantic palaeocirculation since 45 ka B.P., Barra Fan, margin, U.K., Paleoceanography, 16, 53-64, 2001.

Kroopnick, P. M., The distribution of ${ }^{13} \mathrm{C}$ of total $\mathrm{CO}_{2}$ in the world oceans, Deep Sea Res., 32, 57-77, 1985.

Labeyrie, L., H. Leclaire, C. Waelbroeck, E. Cortijo, J.-C. Duplessy, L. Vidal, M. Elliot, and B. Le Coat, Temporal variability of the surface and deep waters of the North West Atlantic ocean at orbital and millennial scales, in Mechanisms of Global Climate Change at Millennial Time Scales, Geophys. Monogr. Ser, vol. 112, edited by P. U. Clarke, R. S. Webb, and L. D. Keigwin, pp. 77-98, AGU, Washington D.C., 1999.

Lagerklint, I. M., and J. D. Wright, Late glacial warming prior to Heinrich event 1: The influence of ice rafting and large ice sheets on the timing of initial warming, Geology, 27, 10991102, 1999.

Lassen, S., A. Kuijpers, H. Kunzendorf, H. Lindgren, J. Heinemeier, E. Jansen, and K. L. Knudsen, Intermediate water signal leads surface water response during Northeast Atlantic deglaciation, Global Planet. Change, 32, 111-125, 2002.

Lehman, S. J., and L. D. Keigwin, Sudden changes in North Atlantic circulation during the last deglaciation, Nature, 356, 757-762, 1992.

MacAyeal, D. R., Binge/purge oscillations of the Laurentide ice sheet as a cause of the North Atlantic's Heinrich events, Paleoceanography, 8, 775-784, 1993.

McCabe, A. M., and P. U. Clark, Ice sheet variability around the North Atlantic Ocean during the last deglaciation, Nature, 392, 373-377, 1998.

McCartney, M. S., Recirculation components to the deep boundary current of the northern North Atlantic, Prog. Oceanogr., 29, 283-383, 1992.

McCartney, M. S., and L. D. Talley, Warm-to-cold water conversion in the northern North-Atlantic ocean, J. Phys. Oceanogr., 14, 922-935, 1984.

McCave, I. N., B. Manighetti, and N. A. S. Beveridge, Circulation in the glacial North Atlantic inferred from grain-size measurements, Nature, 374, 149-152, 1995a.

McCave, I. N., B. Manighetti, and S. G. Robinson, Sortable silt and fine sediment size composition slicing: Parameters for palaeocurrent speed and palaeoceanography, Paleoceanography, 10, 593-610, 1995b.

New, A. L., and D. Smythe-Wright, Aspects of the circulation in the Rockall Trough, Cont. Shelf Res., 21, 777-810, 2001 . 
Oppo, D. W., and S. J. Lehman, Mid-Depth circulation of the Subpolar North Atlantic during the Last Glacial Maximum, Science, 259, 1148-1152, 1993.

Rasmussen, T. L., E. Thomsen, T. C. E. Van Weering, and L. Labeyrie, Rapid changes in surface and deep water conditions at the Faroe Margin during the last 58,000 years, $\mathrm{Pa}$ leoceanography, 11, 757-771, 1996.

Ruddiman, W. F., and A. McIntyre, The North Atlantic during the Last Deglaciation, Palaeogeogr. Palaeoclimatol. Palaeoecol., 35, 145-214, 1981.

Sarnthein, M., K. Winn, S. J. A. Jung, J.-C. Duplessy, L. Labeyrie, H. Erlenkeuser, and G. Ganssen, Changes in East Atlantic deep water circulation over the last 30,000 years: Eight time-slice reconstructions, Paleoceanography, 9, 209267, 1994.

Sarnthein, M., et al., Variations in Atlantic surface paleoceanography, $50-80^{\circ} \mathrm{N}$ : A time slice record of the last 30,000 years, Paleoceanography, 10, 1063-1094, 1995.

Scourse, J. D., I. R. Hall, I. N. McCave, J. R. Young, and C. Sugdon, The origin of Heinrich layers: Evidence from $\mathrm{H} 2$ for European precursor events, Earth Planet. Sci. Lett., 182, 187-195, 2000.

Sejrup, H. P., H. Haflidason, I. Aarseth, E. King, C. F. Forsberg, D. Long, and K. Rokoengen, Late Weichselian glaciation history of the northern North Sea, Boreas, 23, 1-13, 1994.

Stoner, J. S., J. E. T. Channell, and C. Hillaire-Marcel, The magnetic signature of rapidly deposited detrital layers from the deep Labrador Sea: Relationship to North Atlantic Heinrich layers, Paleoceanography, 11, 309-325, 1996.

Stuiver, M., P. J. Reimer, E. Bard, J. W. Beck, G. S. Burr, K. A. Hughen, B. Kromer, G. McCormac, J. VanderPlicht, and M. Spurk, INTCAL98 radiocarbon age calibration, 24,000-0 cal BP, Radiocarbon, 40, 1041-1083, 1998.

van Kreveld, S., M. Sarnthein, H. Erlenkeuser, P. Grootes, S. Jung, M. J. Nadeau, U. Pflaumann, and A. Voelker, Potential links between surging ice sheets, circulation changes, and the Dansgaard-Oeschger cycles in the Irminger Sea, 60-18 kyr, Paleoceanography, 15, 425-442, 2000.

Voelker, A. H. L., M. Sarnthein, P. M. Grootes, H. Erlenkeuser, C. Laj, A. Mazaud, M. J. Nadeau, and M. Schleicher, Correlation of marine $\mathrm{C}-14$ ages from the Nordic seas with the GISP2 isotope record: Implications for C-14 calibration beyond 25 ka BP, Radiocarbon, 40, 517-534, 1998.

Vorren, T. O., K. D. Vorren, T. Alm, S. Gulliksen, and R. Lovlie, The last deglaciation (20,000 to $11,000 \mathrm{BP})$ on Andøya, northern Norway, Boreas, 17, 41-77, 1988.

Waelbroeck, C., J. C. Duplessy, E. Michel, L. Labeyrie, D. Paillard, and J. Duprat, The timing of the last deglaciation in North Atlantic climate records, Nature, 412, 724-726, 2001.

Zaragosi, S., F. Eynaud, C. Pujol, G. A. Auffret, J.-L. Turon, and T. Garland, Initiation of the European deglaciation as recorded in the northwestern Bay of Biscay slope environments (Meriadzek Terrace and Trevelyan Escarpment): A multi-proxy approach, Earth Planet. Sci. Lett., 188, $493-$ 507, 2001. 